\title{
Water Quality Investigation by Physicochemical Parameters of Drinking Water of Selected Areas of Kureken Sani, Kumbotso Local Government Area of Kano
}

\author{
Aminu Sharif Hassan ${ }^{1, ~ *}$, Isma'il Bello Abubakar ${ }^{2}$, Auwalu Musa ${ }^{3}$, Murtala Tijjani Limanchi ${ }^{4}$ \\ ${ }^{1}$ Department of Physical and Health Education, School of Science Education, Sa'adatu Rimi College of Education, Kumbotso, Nigeria \\ ${ }^{2}$ Child Development Centre, Sa'adatu Rimi College of Education, Kumbotso, Nigeria \\ ${ }^{3}$ Quality Control Laboratory, Tamburawa Water Treatment Plant, Tamburawa, Nigeria \\ ${ }^{4}$ Department of Chemistry, School of Science, College of Art, Science and Remedial Studies, Sabon Gari, Nigeria
}

\section{Email address:}

sdeens1989@yahoo.com (A. S. Hassan)

*Corresponding author

\section{To cite this article:}

Aminu Sharif Hassan, Isma'il Bello Abubakar, Auwalu Musa, Murtala Tijjani Limanchi. Water Quality Investigation by Physicochemical Parameters of Drinking Water of Selected Areas of Kureken Sani, Kumbotso Local Government Area of Kano. International Journal of Mineral Processing and Extractive Metallurgy. Vol. 2, No. 5, 2017, pp. 83-86. doi: 10.11648/j.ijmpem.20170205.14

Received: September 2, 2017; Accepted: September 20, 2017; Published: October 26, 2017

\begin{abstract}
There are different sources through which groundwater becomes contaminated and these includes organic wastes, industrial effluents, urban runoff, agricultural activities, geological factors as well as others. Kureken Sani is a newly developed residential area with scattered settlements. The purpose of this research was to analysed the physicochemical parameters from the area and to compare with the standards given by World Health Organization (WHO) and Nigeria Standard for Drinking Water Quality (NSDWQ). Three samples were collected from different locations for the analysis. The parameters analyzed are $\mathrm{pH}$, temperature, Total dissolved solids, Total suspended solids, Suspended solid, Electrical conductivity, Alkalinity, $\mathrm{Mg}^{2+}, \mathrm{Ca}^{2+}$, colour, free $\mathrm{Co}_{2}$, turbidity, Total hardness and Chloride. The results indicated that all the parameters analyzed are within the permissible limits recommended by World Health Organization (WHO) and Nigerian Standard for Drinking Water Quality (NSDWQ) with exception of turbidity level at YS sampling station, $\mathrm{Mg}^{2+}$ concentration at DS and YS sampling point and total hardness from sampling point DS.
\end{abstract}

Keywords: Physicochemical Parameters, Kureken Sani, Water Quality, Total Hardness, Alkalinity

\section{Introduction}

Water is the essence of life and soft drinking water is basic human right essential to all and also essential for the wellbeing of mankind and for sustainable development [1]. According to [2] the importance of water ranges from cooking, drinking, agricultural and industrial processes, human recreation and waste disposal. The availability of good water is an indispensable feature for preventing diseases and improving quality of life [3-4]. Water quality deals with the physical, chemical, and biological characteristics in relation to all other hydrological properties [4].[5] Reported that, the quality of ground water depends on various chemical constituents and their concentration, which a mostly derived from the geological data of the particular region. According to WHO (2002), over 1 billion people lack access to safe drinking water worldwide. The situation is worse in developing countries where many people especially the poor have opted to using the ground drinking water sources like boreholes, shallow wells, springs, as a source of drinking water and for other domestic use [6]. It was observed by [7] that, the cost of environmental degradation due to water changes i.e pollution is relatively high with serious health and quality of life consequences; as well as measuring the severity of water scarcity problems. Zyadah (1996) cited in [7] observed that, increasing water pollution does not only cause deterioration of water quality but also threatens human health, balance of aquatic ecosystems, economics development as well as social prosperity. 
Groundwater contamination has become a great problem due to rapid population growth industrialization and urbanization rate in the metropolitan cities all over the world [8]. The source of contamination may be due to land disposal of sewage effluents, Sludge and solid waste, septic tank effluents urban runoff, agricultural mining and industrial practices [9]. Groundwater can also be contaminated through organic wastes, infiltration, of irrigation water, pits, lagoons and ponds used for storage [10]. Therefore, it is of paramount importance to assess both physical and chemical standard of groundwater as it is the only source of drinking water within the study area, to improve awareness educate, and reduce the incidence of diseases transmission [9].

\section{Materials and Method}

\subsection{Study Area}

The study was conducted in Kureken Sani, Kumbotso local government area of Kano State, Nigeria. Kumbotso lies between $11^{0} 53$ '17" $\mathrm{N}$ latitudes and $8^{0} 30^{\prime} 11^{\prime \prime} \mathrm{E}$ longitude. It has an area of $158 \mathrm{~km}^{2}$ and a population of 295979 as at 2006. It shares boundaries with Gwale, Tarauni, Kano Municipal and Ungogo to the north, Dawakin Kudu and Warawa to the east, Madobi Local Government to the south, while Tofa and Rimingado to the west [11].

\subsection{Sampling Techniques}

The samples were collected from three stations i.e Yanlemo Street (YS), Dagaci Street (DS) and behind Juma'at Mosque (JM) all in Kureken Sani from Kumbotso local government area. The sample was collected in a sterilized $50 \mathrm{cl}$ plastic container [9] and were transported to the Tamburawa water treatment plant central laboratory for analysis.

\subsection{Physicochemical Analysis}

The parameters analyzed are $\mathrm{pH}$, temperature, Total dissolved solids, Total suspended solids, Suspended solid, Electrical conductivity, Alkalinity, $\mathrm{Mg}^{2+}, \mathrm{Ca}^{2+}$, colour, free $\mathrm{Co}_{2}$, turbidity, The analysis were carried out in accordance with standard method of American Public Health Association [12-13]. The temperature, $\mathrm{pH}, \mathrm{EC}$, and TDS were determined at the sampling point using a portable hand-held DC-powered Hanna HI 88129 digital thermometer with a glass sensor. Total hardness $(\mathrm{TH})$, magnesium $\left(\mathrm{Mg}^{2+}\right)$ and calcium $\left(\mathrm{Ca}^{2+}\right)$ were determined by the volumetric method with EDTA. Alkalinity was analysed by volumetric dosage with $\mathrm{O} .1 \mathrm{~N}$ $\mathrm{HCl}$ solution and chloride was determined by the volumetric method [10].

\section{Result}

The results of the physicochemical parameters analyzed in the water of the three sampling point are presented in table 1 below.
Table 1. Results of Physicochemical Parameters.

\begin{tabular}{llll}
\hline PARAMETERS & JM & DS & YS \\
\hline $\mathrm{T}\left({ }^{\circ} \mathrm{C}\right)$ & 28.00 & 27.8 & 27.7 \\
$\mathrm{pH}$ & 8.30 & 7.80 & 7.80 \\
$\mathrm{TH}(\mathrm{mg} / \mathrm{L})$ & 116.72 & 691.30 & 170.59 \\
$\mathrm{TDS}(\mathrm{mg} / \mathrm{L})$ & 143.70 & 402.00 & 168.10 \\
$\mathrm{SS}(\mathrm{mg} / \mathrm{L})$ & 30.20 & 52.30 & 44.00 \\
$\mathrm{TSS}(\mathrm{mg} / \mathrm{L})$ & 113.50 & 349.70 & 124.10 \\
$\mathrm{Ca}^{2+}(\mathrm{mg} / \mathrm{L})$ & 36.01 & 117.16 & 27.04 \\
$\mathrm{Mg}^{2+}(\mathrm{mg} / \mathrm{L})$ & 80.71 & 574.14 & 143.55 \\
$\mathrm{Cl}^{-}(\mathrm{mg} / \mathrm{L})$ & 34.55 & 16.28 & 66.13 \\
$\mathrm{EC}(\mu \mathrm{s} / \mathrm{cm})$ & 290.00 & 803.10 & 335.10 \\
$\mathrm{Turbidity}(\mathrm{NTU})$ & 4.00 & 4.00 & 8.00 \\
$\mathrm{Colour}(\mathrm{TCU})$ & 5 & 10 & 6 \\
Free C0 $2(\mathrm{mg} / \mathrm{L})$ & 10.00 & 30.00 & 16.00 \\
Alkalinity $(\mathrm{mg} / \mathrm{L})$ & 32.50 & 29.00 & 21.50 \\
\hline
\end{tabular}

\section{Discussion}

Conductivity in all the water sampled analysed are below the maximum limits of $1000 \mu \mathrm{S} / \mathrm{cm}$ prescribed by [14]. The values ranged between $290.00-803.10 \mu \mathrm{S} / \mathrm{cm}$, high value was recorded from Sampling point DS and low value at Sampling point JM. Conductivity in water is a measure of all ions dissolved (soluble salts) [15]. Turbidity measurements in water are a key test of water quality as high turbidity in water may indicate ineffectiveness in filtration [16]. The turbidity of the samples analyzed varied between 4-8NTU which falls within 5NTU recommended values by [14], except sample YS which is higher. The lowest values were found at JM and DS. Alkalinity is another parameter in water quality study;it is the acid neutralizing capacity of water and a function of all titratable bases present in water (Yakasai and Atiku, 2010) in [16]. The alkalinity values ranged between $21.50-32.50 \mathrm{mg} / \mathrm{l}$, with maximum values of $32.50 \mathrm{mg} / \mathrm{l}$ and minimum value of $21 / 50 \mathrm{mg} / \mathrm{L}$ at $\mathrm{JM}$ and YS respectively. The values were found to be below the prescribed limit of $500 \mathrm{mg} / \mathrm{L}$ by [14]. $\mathrm{pH}$ is among the most important parameters in operational water quality study and is the measurement of acid base equilibrium in water [16]. From the results, the highest values was recorded at JM and lowest at DS and YS which falls within the recommended levels of $6.5-8.5$ by $[14,17]$ and the $\mathrm{pH}$ was slightly basic.

The temperature is one the most essential parameters in water. It has significant impact on growth and activity of ecological life and is greatly affects the solubility of oxygen in water [12]. The values obtained ranged from 27.7$28.00^{\circ} \mathrm{C}$. The highest value was found to be $28.00^{\circ} \mathrm{C}$. Chlorides are common constituents of all natural waters. Higher value of it impart a salty tasty to water making it unacceptable for human consumption. The values of chlorides range from $16.28-66.13 \mathrm{mg} / \mathrm{L}$. The maximum value of $66.13 \mathrm{mg} / \mathrm{L}$ was recorded at $\mathrm{YS}$ and minimum value of $16.28 \mathrm{mg} / \mathrm{L}$ at DS. In the present study value of chlorides was found to be below the presubscribed limit of $250 \mathrm{mg} / \mathrm{L}$ recommended by $[14,17]$. Free $\mathrm{Co}_{2}$ was found within the range of $10.00-30.00 \mathrm{mg} / \mathrm{L}$. the maximum value of $30 \mathrm{mg} / \mathrm{L}$ was recorded at the sampling site DS and minimum at JM. This may be depends upon alkalinity and hardness of water 
body as reported by [18].

Our study found that, colour values ranged between 510TCU, which is within WHO permissible limit. According to [19], colour in drinking water is usually due to the presence of colour organic matter associated with the humus fraction of soil or the presence of iron and other metals, either as natural impurities or as corrosion products. From results obtained, it was observed that, the values of suspended solids varies between $30.20-52.30 \mathrm{mg} / \mathrm{L}$ with higher values at DS and lower at sampling point JM. The result shows that TDS ranged from 143.70-402.00 $\mathrm{mg} / \mathrm{L}$. According to [6] high concentrations above the WHO recommended value affect the test of drinking water quality. The TDS in all the water samples were far below the WHO maximum allowable limit of $1000 \mathrm{mg} / \mathrm{L}$, making these water sources suitable for drinking. Total dissolved solids indicate the salinity of groundwater. TSS values presents a minimum value of 113.50 at $\mathrm{JM}$ and a maximum value of $349.70 \mathrm{mg} / \mathrm{L}$ at DS. The values obtained varies from $113.50-349.70 \mathrm{mg} / \mathrm{L}$. The lowest value of calcium $27.04 \mathrm{mg} / \mathrm{L}$ was recorded at sampling point YS and the highest value was found to be $117.16 \mathrm{mg} / \mathrm{L}$ at sampling point DS. The results show that, the values falls within the maximum permissible limits of 100$300 \mathrm{mg} / \mathrm{L}$ set by [14]. The magnesium in the water samples was found to be in the ranged of $80.71-574.14 \mathrm{mg} / \mathrm{L}$. The result shows that sampling point DS recorded the highest value of $574.14 \mathrm{mg} / \mathrm{L}$ while $\mathrm{JM}$ has the lowest value of $80.71 \mathrm{mg} / \mathrm{L}$. the results, also indicated that only the sample from JM falls within the recommended levels set by NSDWQ, while DS \& YS was higher than the maximum permissible limits.

The hardness levels were also analyzed and presented in table 1. Based on the classification of water conducted by Roxane and Tom (2012) cited in [20] in regard to water softness or hardness almost all the water samples, analyzed are hard. The results indicated that the water samples are safe for drinking and other domestic purposes. The minimum value of $116.72 \mathrm{mg} / \mathrm{L}$ was recorded at $\mathrm{JM}$ and maximum of $691.30 \mathrm{mg} / \mathrm{L}$ at DS.

\section{Conclusion}

Water quality deals with the physical, chemical, and biological characteristics in relation to all other hydrological properties. The quality of ground water depends on various chemical constituents and their concentration, which a mostly derived from the geological data of the particular region. There are different sources through which groundwater becomes contaminated and these includes organic wastes, industrial effluents, urban runoff, agricultural activities, geological factors as well as others. Kureken Sani is a newly developed residential area with scattered settlements. Three samples were collected from different locations for the analysis. The parameters analyzed are $\mathrm{pH}$, temperature, Total dissolved solids, Total suspended solids, Suspended solid, Electrical conductivity, Alkalinity, $\mathrm{Mg}^{2+}, \mathrm{Ca}^{2+}$, colour, free $\mathrm{Co}_{2}$, turbidity, Total hardness and Chloride. The results indicated that all the parameters analyzed are within the permissible limits recommended by WHO and NSDWQ with exception of turbidity level at YS sampling station, $\mathrm{Mg}^{2+}$ concentration at DS and YS sampling point and total hardness from sampling point DS.

\section{References}

[1] Musa, J. J., Adejumo, B. A and Fumen, G. A. (2013), "Comparative Analysis of Water Samples from three different Sources (A case Study of Bosso, Minna Niger State)". Journal of Environmental Science, Toxicology and Food Technology, 4 (5): $6-10$.

[2] Zubia, Mosood et al. (2015) "Analysis of Physicochemical Parameter of Water and Sediments Collected from Rawal Dam Islamabad"American-Eurasian Journal of Toxicological Science, 7 (3): 123-128.

[3] Patil, P. N, Sawant, D. V and Deshmukh, R. N (2012). "Physicochemical Parameters for testing of water- A review". International Journal of Environmental Sciences, 3 (3).11941207.

[4] M. M, Ruma et al. (2014). "Assessment of some physicochemical parameters levels in Sachet Drinking Water and its Effects on Human Health in Katsina urban Area, Nigeria”. Science World Journal 9(1): 19-27.

[5] I. Y Chindo et al. (2013). "Physicochemical Analysis of Groundwater of Selected Areas of Dass and Ganjuwa local Government Areas, Bauchi State Nigeria". World Journal of Analytical Chemistry, 1(4): 73-79.

[6] Lukubye, B. and Andama M. (2017) "Physicochemical Quality of Selected Drinking Water Sources in Municipality Uganda". Journal of Water Resources and Protection, 9, 707722 .

[7] El-Amier, Y. A, El-kawy Zahran, M. A and Al-mamory, S. H (2015) "Assessment the Physicochemical Characteristics of Water and Sediment in Rosetta Branch, Egypt". Journal of Water resource and Protection, 7, 1075-1086.

[8] B. S. Badmus et al. (2014). "Groundwater Assessment of Hand Dug Well Around open Landfill in Ibadan Metropolis for Domestic and Irrigation Purposes" Journal of water resource and protection, $6,142-1424$.

[9] Allamin, I. A., Borkoma, M. B., Joshua, R. and Machina, I. B. (2015) "Physicochemical and Bacteriological Analysis of Well Water in Kaduna Metropolis Kaduna State". Open Access Library Journal 2:e1597.

[10] Said, L., Abdulaziz, A. and Abdullah E. A. (2014). Determination of Physicochemical Parameters of Spring Water in Sebt Jahjour area (El-Hajb, Morocco)". Development in Analytical chemistry, 1, 15-18.

[11] Yelwa, N. A. et al. (2015) "Groundwater Prospecting and Aquifer Delineation Using Vertical Electrical Sounding (VES) Method in the Basement Complex Terrain of Kumbotso LGA of Kano State Nigeria" Journal of Applied Geology and Geophysics, 3 (1): 01-06.

[12] American Public Health Association (APHA, 1998), Study Standard Methods for the Examination of Water and Wastewater 20 Edition. Washington DC. 
[13] FAO (1997). "Chemical Analysis Manual for Food and Water. $5^{\text {th }}$ Edition FAO, ROME, 20-26.

[14] WHO (2006) Guidelines for Drinking Water quality $3^{\text {rd }}$ Edition, WHO Press, Geneva, 398.

[15] Dahiru M. and O. I., Enabulele (2015) "Microbiological and Physicochemical Evaluation of Jakara canal Wastewater used for Irrigation in Kano". International Journal of Microbiology and Application, 2(2): 25-30.

[16] Abdullahi, U. A and Indabawa I. I. (2012) "Study of Physicochemical and heavy metals ( $\mathrm{Pb}, \mathrm{Fe}, \mathrm{Mn})$ Concentrations of Tap Water in Dutse, Jigawa State, Nigeria" Bayero Journal of pure and Applied Sciences, 5(2): 89-82.

[17] NSDWQ (2007). Nigerian Standard for Drinking Water Quality. NIS 554, Son, Lagos, 30.
[18] Basavara, S. et al. (2011) "Analysis of water Quality Using Physicochemical Parameters Hosahalli Tank in Shimoga District, Karnataka India". Global Journal of Science Frontier Research, 11(3).

[19] Emmanuel B. and N. Ayeni (2012). "Physicochemical Analysis of Groundwater Samples of Bichi Local Government Area of Kano State of Nigeria". World Environment, 2(6): 116-119 DOI: 10.5923/j.env.20120206.02.

[20] Saeed, M. D. and Mahmoud A. M. (2014) "Determination of Some Physicochemical Parameters and Some Heavy Metals in Boreholes from Fagge L.G.A of Kano Metropolis Kano State Nigeria". World Journal of Analytical Chemistry, 2(2): 42-46. 